\title{
In the aftermath of the Bologna process: exploring the master students' perceptions on accounting in two portuguese higher education institutions*
}

\author{
Cristina Góis (cgois@iscac.pt) \\ Coimbra Business School (Portugal) \\ Filomena Antunes Brás (filomena@eeg.uminho.pt) \\ University of Minho (Portugal) \\ http://dx.doi.org/10.12795/EDUCADE.2013.104.04
}

\begin{abstract}
This paper explores how accounting is perceived [supported on Geiger and Ogilby (2000) paper] and which factors may influence these perceptions by students of seven master's programmes taught in two different Portuguese higher education institutions. These aims are important in the context of the impact of the Bologna process in the Portuguese Higher Education System. The study also explores whether those perceptions are associated with the students' performance in the accounting course.
\end{abstract}

This is the first study (as far as the authors know) on students' perceptions on accounting in Portugal, but also one of the few in a context of master's programmes (advanced graduation) in the accounting education literature.

A survey was conducted at two different moments in time to explore how master's students' perceptions evolve through the semester.

The results of this study show a change in perceptions over the semester. At first, accounting course was perceived as very important in the master programme, as helping the professional career and rewarding, and therefore students were very motivated. At the end, all the perceptions values decreased in general. However, student's perception on lecturer's role in making them understand the subject and its utility increased significantly as well they enjoyed learning accounting. The results also show controversial evidence of student's characteristics as influencing students' perceptions on accounting. The students' perceptions have a marginal effect on the final grade, in which male and female students perform significantly different.

KEYWORDS: perceptions; accounting; higher education; Portugal; survey

\section{*Acknowledgements}

The authors would like to thank the students who participate in the survey, as well as the participants of the XX Portuguese-Spanish Annual Conference on Scientific Management in Setubal (Portugal), 4-5th February, 2010 and the participants of the 2010 BAA Accounting Education SIG Annual conference, Dublin (Ireland), 26-28th May, anonymous referees and the Editor of Educade for their comments on earlier drafts of this paper. The authors also wish to acknowledge the financial support provided by the Foundation for Science and Technology (FCT) - Portugal.

Artículo de investigación. Recibido: 08-02-13 - Versión revisada: 11-03-13, 26-03-13, Aceptado: 10-04-13

Licencia Creative Commons BY NC ND · 2013 · Asociación Española de Contabilidad y Administración de Empresas - AECA 


\section{INTRODUCTION}

Students' perceptions on accounting are a very important field in the accounting education literature because they "affect whether the supply of talent will be sufficient for the profession to thrive" (AECC, 1992. p. 2). The importance of the first course in accounting for accounting or management education has been discussed in the literature (e.g., Baldwin and Ingram, 1991; Geiger and Ogilby, 2000). However, no prior study, that we are aware of, has considered students' perceptions in a context of "radical restructuring" of the "higher education systems" as it happens with Bologna Process (Keeling, 2006. p. 206).

Bologna Process is an intergovernmental commitment of European countries to restructuring higher education systems, to establish the "European Higher Education Area" of compatible national systems (Keeling, 2006). Taking part of the Bologna Process was a voluntary decision made by each country and its higher education community to endorse the principles underlined in the European Higher Education Area (EUA, 2012). These principles include the creation of a comparable structure of academic degrees, mutual recognition of diplomas and course units, the assessment of academic institutions and programs based on common quality standards and direct incentives for geographical mobility of students and staff (Cardoso et al., 2008).

In 2006, the Bologna Process was implemented in Portugal, and it had a strong impact on the Portuguese higher education system. In general, all the undergraduate degrees have been shortened to three years long.

According to Cardoso et al. (2008), Bologna Process introduced a two-tier system of three-year bachelor's degrees and two-year master degrees, as in the UK, US, Canada, Australia and India. This new system presents some advantages (Jacobs and van der Ploeg, in Cardoso et al., 2008. p. 231). On the one hand, students can complete their studies more quickly. On the other hand, a two-tier system reduces the cost of wrong choices made by students. The two-tier system also promotes a more flexible progression into postgraduate studies by allowing students to enter the labor market sooner and to find out what competences they should develop when they go back to the higher education system to take a Master's degree. Therefore, it is possible to find students in accounting courses at business or accounting master degrees without holding an accounting degree or ever having learned accounting. Before the education system reform, the master degree was a specialization chosen after the student's undergraduate degree and decided according to the field of work.

However, Bologna Process advantages are seen as controversial. Distrust has been expressed over the academic contents of the curricula and the adequacy to labor market needs of the competencies gained in a shorter three-year period, with fears that the employability of graduates will be reduced, when compared to graduates of the longer cycle (Cardoso et al., 2008). Besides, Bologna Process underlines the assumption of lifelong learning, which reinforces the demand for a master degree. At the same time, Portuguese accounting standards have changed due to the international harmonization movement. Whole these factors have meant the increasing demand for a master degree.

Accordingly, this paper aims to contribute to the study of higher education in Portugal and the accounting education in particular. This paper aims to explore whether accounting perceptions of advanced students are any different from those documented at the undergraduate level in the accounting education literature (e.g., Geiger and Ogilby, 2000; Malgwi, 2006), when considering the first course in accounting at the master degree. Understanding the perceptions of the accounting course is 
important since the student's population at master degree has deeply changed and some concerns have risen about the accounting education at the advanced graduation. Also, this paper seems to be the first to study the Portuguese higher education system in the aftermath of the Bologna Process reform and in the education accounting context.

To achieve the aims of this exploratory study, a questionnaire survey was conducted at two Portuguese higher education institutions, representing two different education systems. Seven master's programmes were considered for the study.

The main conclusions are that there is no significant difference between the university and polytechnic systems on the students' perceptions on accounting and on their final grade of the accounting course. However, there is empirical evidence supporting that polytechnic system attracts students with different characteristics than those attracted by the university system. The study also shows the importance of the lecturer in developing students' perceptions on accounting and there is indication of superior performance achieved by male students compared to female students.

The paper is structured in the following way. After introducing the main issue of the paper, a literature review on accounting education is presented, mainly concerning students' perceptions when studying accounting and the relation of students' characteristics to student performance. Then, in section three, the Portuguese Higher Education System is presented, as well as its evolution in the Bologna Process context and its two main approaches on teaching aims. Afterwards, in section four, the methodology process of the paper and its research framework are described. In section five, the results are presented and discussed. The study is completed with the presentation of the main limitations and suggestions for future research.

\section{LITERATURE REVIEW}

The accounting literature presents several perspectives on perceptions about accounting and accountants. While one perspective describes accountants in terms of their personality characteristics and appearance, others describe them by the skills and capabilities required the nature of the duties they perform, and in terms of career choice factors (Wells, 2009). Although the first perspective is not on issue in this paper, the other two perspectives are important.

\subsection{Perceptions on Accounting Profession and Accounting Education}

There are several studies that report the perceived nature of the duties performed by accountants. They have characterised the accountant's work as being interesting or boring, imprecise or accurate, novel or methodical (Donelan and Reed, 1992; Cohen and Hanno, 1993; Saemann and Crooker, 1999; Albrecht and Sack, 2000; Hardin et al., 2000; Byrne and Willis, 2005; Wells and Fieger, 2006; Malthus and Fowler, 2009). They all have concluded that the duties performed by accountants were negatively perceived. This finding suggests that students can also perceive accounting as boring, methodical and difficult.

Other studies have researched the relationship between the accounting profession and the accounting education. For example, Arendale (1994) suggested that accounting education should be more attractive to encourage and motivate students at the introductory level. In turn, Rao and Higgins (1999) attempted to measure the accounting subject significance as a useful function to society, according to the users' perspective. They concluded that most people perceived accounting information as being useful to society, though it was considered a difficult course. 
In order to improve the recognition of the accounting courses, the pedagogy analysis was introduced. Papers of Williams (1991) and Baldwin and Ingram (1991) have been considered the most important studies in this area. Williams (1991) was oriented to measure the students' attractiveness to the accounting education and to analyse the accounting curricula relevance. Baldwin and Ingram's (1991) paper was oriented to find the major reasons that explained the decline of accounting's popularity. Their findings have showed that accounting education has failed to demonstrate why accounting information is useful. Therefore, these findings suggest that students do not perceive accounting as useful for their professional performance or career development.

Perceptions on accounting profession are an important factor to attract people to study accounting or to develop a career in accounting. Several studies have dealt with students' perceptions on the accounting profession (ex: Paolillo and Estes, 1982; Inman et al., 1989; Saemann and Crooker, 1999). Harrison (1998) suggested that students' perceptions are important but the perceptions of people that surround them are also important. For this reason, Nelson et al. (2002) advocated that accounting professionals should monitor society agents' perceptions, including students, to ensure that future students perceive accounting correctly. A misleading perception may lead the wrong people to follow an accounting career and to leave out those who should perform an accounting career.

Marriott and Marriott (2003) conducted a study on students' perceptions concerning accounting as a profession, after studying in two universities from the UK with different systems on teaching: one considered as traditional and the other one considered as novel. They have submitted a questionnaire to students at their first stage and then at the end of their final stage of the programme. Using Nelson's "Accounting Attitude Scale", Marriott and Marriott (2003. p.116) concluded that at the beginning of their studying process there was a positive perception on accounting as a profession, but it decreased by the end of the course. Although students perceived the job of accountants as a respectful profession, students considered it more relevant and interesting at the beginning of the course than at the end. This conclusion was valid for both institutions, although they presented different programme courses and teaching methods. Their findings suggest that students' perceptions on accounting evolved negatively over the accounting course, apart of the institution, course or teaching methods in which they were enrolled.

\subsection{Factors that Influence Perceptions on Accounting Profession and Accounting Education}

Literature on what influences perceptions on accounting and accountants has identified some factors that explained the perceived negative and inaccurate perceptions (Wells, 2009). Geiger and Ogilby (2000) studied the students' perceptions of the first course in accounting and the effect of these perceptions on deciding whether or not to major in accounting. Their results showed a significant individual instructor association that reinforces the need for accounting programmes, as well as educational institutions, to be selective in their assigning instructors to the first accounting course (AECC, 1992). In the same stream of research, Malgwi (2006) investigated whether there were differences in perception among students, using as criteria major in accounting and gender in order to ascertain whether these differences were significant enough to suggest the need for separate course delivery. His findings showed that one third of the students perceived the first course in accounting as significantly important to their future career, irrespective of their major and gender. The results also showed that accounting majors have higher positive perceptions of the accounting attributes than the non-accounting majors. These findings suggest that the 
importance of accounting to future student's career does not depend of the student's major or gender.

\subsection{The Role of the Lecturer in Students' Perceptions on Accounting}

In another research stream, different authors have explored the role of the lecturer in influencing students' perceptions, advocating that the lecturer (teacher) is a key factor in the way he/she influences the students' perceptions on accounting. Hardin et al. (2000), Berry et al. (2004) and Sugahara et al. (2006) found that teachers had a weak perception on the accountancy profession and transmitted their perception to students, whereas Malthus and Fowler (2009) found accounting educators to have a favourable view of a career in accounting. Also Geiger and Ogilby (2000) found empirical support between teachers and changes in students' perceptions during the first accounting course. These studies give support to the argument that teachers' perceptions on accounting career are important in influencing students to graduate in accounting.

\subsection{The Role OF Gender in Students' Perceptions on Accounting}

Gender differences have been explored in several studies in the accounting education literature (ex: Byrne et al., 2002; Bouillon and Doran, 1992), mostly approaching the ethical issues among accounting profession (e.g., Ameen et al., 2004) or the students' performance (e.g, Mutchler et al., 1987; Lipe, 1989; Buckless et al., 1991; Doran et al., 1991), where there is controversial empirical evidence. In general, studies showed that male students perform better than female ones (Doran et al., 1991). However, gender may also influence the students' perceptions on accounting. It has been reported that female and male students possess different perceptions of the accounting profession. For example, Byrne and Willis (2005) conducted a study with 506 students in Ireland about students' perceptions on the accounting profession. They found that female students sustained a neutral position on accounting profession and the male students considered it boring, although they were students from the secondary school.

As can be noticed, research on students' perceptions on accounting has been conducted mainly at the first stage of student training. Due to the implications of the Bologna Process reform to the higher education systems, and therefore to accounting education, it is interesting to study whether there are any differences on students' perceptions about accounting at advanced graduation level. Compared to students at the undergraduate degree, the master students are older and possess work experience. They pursue a business or an accounting master to help them to perform their present professional tasks. Therefore, the student population under this study is quite different from that studied in the accounting literature at the undergraduate level. However, the question about accounting perceptions sustains and makes it interesting to study in order to better understand the Portuguese Higher System changes. The Portuguese Higher Education System is presented in the next section.

\section{PORTUGUESE HIGHER EDUCATION SYSTEM}

The Portuguese system of higher education is organised as a binary system, with fourteen universities and fifteen polytechnic institutions (Direcção Geral do Ensino Superior, DGES, 2009).

The universities and polytechnic institutions aim to achieve different objectives as far as curricula issues are concerned. The university vocation is to promote research and knowledge development, ensuring a solid scientific and cultural preparation and providing technical training so that a profession that demands conception, innovation 
and critical thinking competences can be performed (DGES, 2009). Here, the aim is to teach students to "learn how to do". In turn, polytechnic institutions are oriented to a constant perspective on applicable and development investigation. Their vocation is to understand and find solutions for concrete problems, aiming to provide a solid cultural and technical training at higher education level, developing innovation skills capacity and critical thinking and providing scientific knowledge in both theoretical and practical dimensions and their applications in order to perform a professional activity (DGES, 2009). Here the aim is to teach students to "learn by doing".

Accounting courses are taught in both institutions. However, an accounting undergraduate degree is only awarded by the polytechnic system (with one university exception), since accountancy is socially perceived as a technical profession. Therefore, the higher education system (institution) is suggested to have some influence in the way accounting is perceived by students.

Up to 2006, Portuguese universities and polytechnics awarded the academic undergraduate degrees of bacharel and/or licenciado while only universities could award postgraduate degrees of master's and doctorate (PhD). However, access to the master's and the doctorate degrees was not straightforward. Only candidates with higher grades could apply to the master's programme. However, universities have also considered other factors for student application assessment such as the curriculum vitae, with relevance for the professional experience. The same happened with the PhD programmes, to which only master's applicants and undergraduate applicants with grades higher than sixteen (in a 0-20 scale) were allowed to access. Therefore, the Portuguese education system was classified as elitist, and the performance of such education system has been highlighted as one of the major reasons for Portugal's somewhat slow convergence with the economies of most of the countries in the European Union (Fernandes, 2009). Hence, the master's degree is very important in the Portuguese context. However, with the implementation of the Bologna Process, the structure of this degree has changed.

The Portuguese Decree-Law regulating the implementation of the Bologna process (Decree-law no. 74/2006 of 24 March) confers universities and polytechnics the possibility of offering the 1st (undergraduate) and 2nd (graduate/master's) Bologna type cycles, while only universities have been allowed to provide doctoral studies. Figure 1 and Figure 2 illustrate the changes operated in the Portuguese Higher Education system due to the Bologna Process.

Each degree provided by the institutions was restructured. Institutions were required to justify changes in their courses/degrees, through comparison to the European panorama in order to achieve the formation of the European Higher Education Area (compatibility and comparability of the higher education systems to enhance mobility of citizens). They were also required to justify how the course units proposed contribute to enhance employability (creation of competences and capabilities necessary to achieve «the most competitive and dynamic knowledge-based economy in the world» (Bergan and Rauhvargers, 2006). But as Lopes and Fernandes (2010. p. 3) stated "institutional arrangements became more strict under Bologna, namely throughout shorter time duration for 1st. cycle completion (from 4 to 3 years, in most Portuguese social sciences graduation programmes) though syllabuses' extension and complexity remained identical most of times".

These changes have led students to perceive that it is not sufficient to hold only an undergraduate degree. The labor market demands a higher level of education. In the accounting field, besides pressures from the regulatory entity of the accountancy profession and the set of international and new national accounting standards, there 
has also been a concern for people aiming to perform accounting or related activities for the purpose of lifelong learning.

figure 1: Portuguese Higher Education system - The University Model

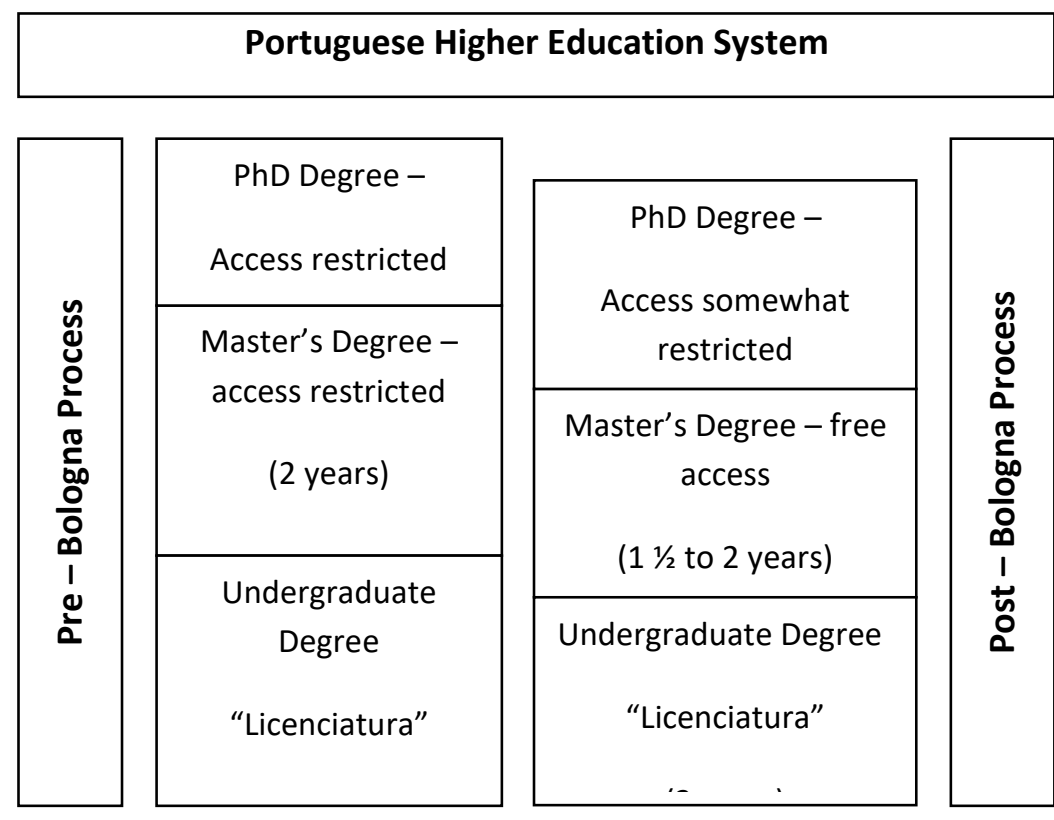

\section{University Education}

Figure 2: Portuguese Higher Education system - The Polytechnic Model

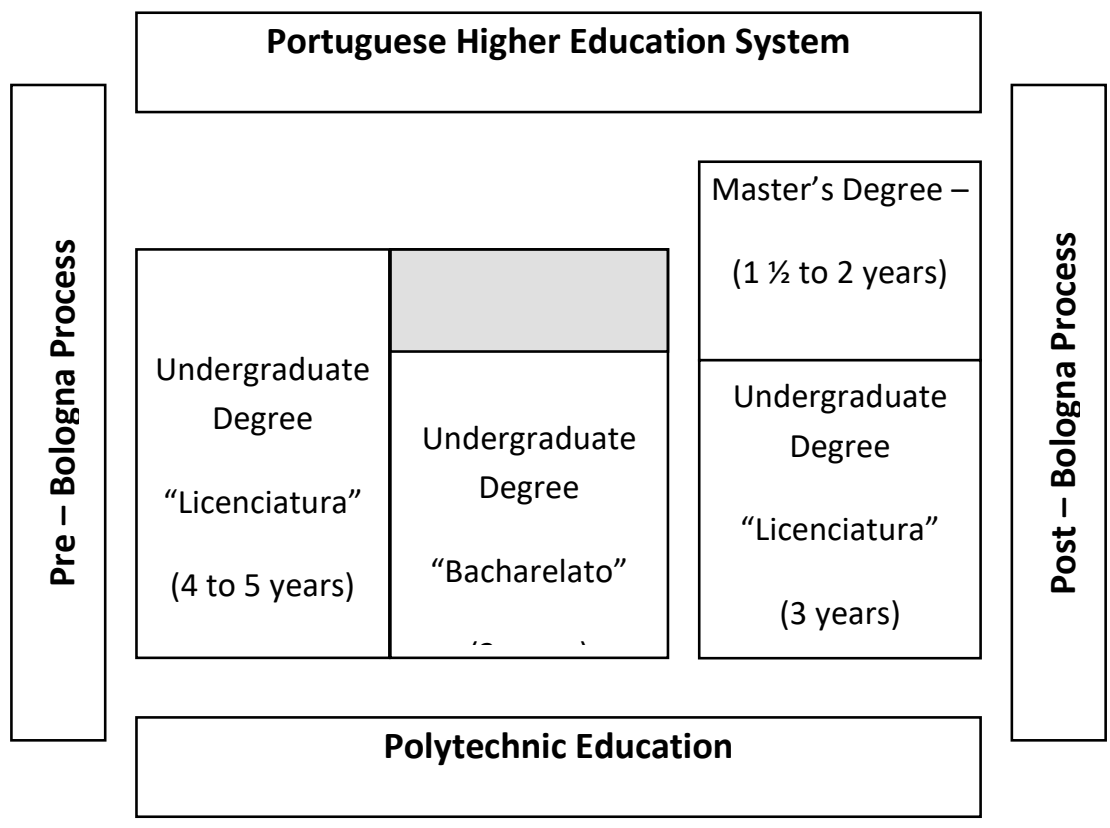

educade, no 4, 2013, p. 40 
Another important feature of the Portuguese Higher Education System is the increasing rate of female students. Female enrolment in higher education has varied depending on the field of study. Initially, it began in areas regarded as socially more acceptable and that allowed women to pursue a professional career. Eventually, women entered other fields of study such as economics, law, medicine and engineering, and became a majority in every degree programme except for the more technological ones (Portuguese Ministry of Science, Technology And Higher Education, MSTHE, 2006). In 2004, among the students enrolled in higher education in Portugal, the female population represented about $61 \%$ of the overall number of students (MSTHE, 2006) and $67 \%$ of the senior graduates were women (Martins et al., 2005). Lopes and Fernandes (2010) stated that this feminisation rate in Portugal is a very noticeable feature because it is higher than the corresponding ones for most European Union (EU) central, southern, Anglo-Saxon countries and even Finland. Therefore, gender and institution may influence students on their perception about accounting. Even though the higher education institutions are under the same regulation as far as the Bologna Process is concerned, the same regulation establishes different education models for each type of institution. This situation raises the question whether that difference influences the master's students' perceptions on accounting.

\section{RESEARCH QUESTIONS}

This paper is an exploratory study. According to Cooper and Schindler (1998. p. 134), exploration is particularly useful when researchers lack a clear idea of the problems they will meet during the study. Through exploration, researchers develop concepts more clearly, establish priorities, develop operational definitions, and improve the final research design (Cooper and Schindler, 1998). In addition, since this is the first attempt to study accounting education by the authors and there are no Portuguese studies on students' perceptions on accounting, as far as the authors are aware of, an exploratory study presents several advantages, namely as a useful way to design a research study as a two-stage design. Thus, this study is a separate first stage. Therefore, in contrast to formal studies, exploratory studies are not typically structured with clearly stated hypotheses. Researchers define a set of subsidiary investigative questions that can be used as guidelines to a detailed research design (Cooper and Schindler, 1998).

Accordingly, the main research question of this study is how master's students perceive accounting and, following Geiger and Ogilby (2000), how that perception evolves through the accounting course, in the context of the aftermath of the Bologna Process implementation. Besides, it attempts to identify which factors influence students' perceptions and whether perceptions affect student performance.

The master student's characteristics under research are: age [there is literature that associates age with student performance (e. g Lane and Porch, 2002), although it was found not significant], gender, work experience after the undergraduate degree (this variable is considered important in the Portuguese context of advanced graduation), institution where the student is enrolled in the master's programme and the graduate degree background (i.e., the undergraduate degree held by the master student). Ramsden (in Ferreira and Santoso, 2008. p. 217) notes that students' characteristics, such as prior knowledge and experience, have the potential to influence students' perceptions, which, in turn, lead to differences in the learning outcomes. Whitworth et al. (2002) found that differences of age, experience and maturity lead graduate students to have significantly higher perceptions of the quality of the teaching than undergraduate students.

The gender of students is a particular variable since, by the early 1990s, women have been the majority of undergraduate and graduate students in all Portuguese 
subsystems of higher education (MSTHE, 2006). Moreover, as presented in the literature review, female students perform accounting course and perceive accounting differently from male students (e.g., Doran et al., 1991; Byrne and Willis, 2005).

The institution in which students are enrolled is also important since it was the Portuguese Ministry of Science, Technology and Higher Education itself that declared the existence of differences that lead institutions to pursue different aims (DGES, 2009).

As a subsidiary question, the study also explores whether the students' academic performance is associated with students' perception on accounting. In prior studies, grade has been frequently used as a proxy for aptitude and prior academic performance (Ferreira and Santoso, 2008; Maksy and Zheng, 2008).

In sum, Figure 3 presents the research framework of this study.

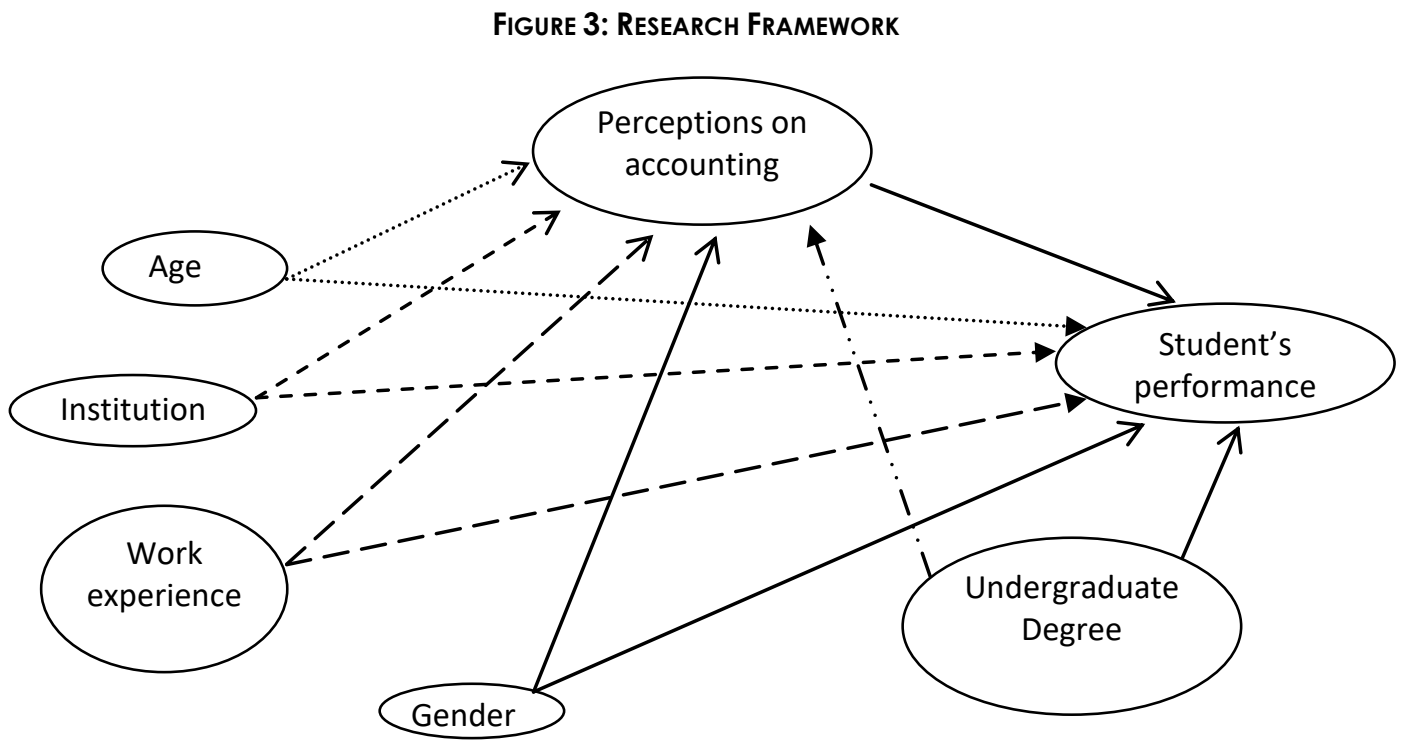

\section{METHODOLOGY}

This section presents how the exploratory study was developed and conducted.

\subsection{QUESTIONNAIRE DESIGN AND ADMINISTRATION}

A questionnaire was conducted to assess master's students' perceptions on accounting based on Geiger and Ogilby (2000) study. This instrument was selected for several reasons, namely the low cost and the incentive used to achieve a high response rate (Cooper and Schindler, 1998; Barañano, 2004). Also, in the education accounting literature, this instrument has been widely used (e.g. Geiger and Ogilby, 2000; Malgwi, 2006).

The main objective is to ascertain how accounting is perceived by the Portuguese master's students in the context of the Portuguese Higher Education System changes derived from the Bologna Process. Thus, the questionnaire was conducted at two different Higher Education Institutions, both located at the North of Portugal and representing two approaches in the Portuguese Higher Education System: a University 
and a Polytechnic. Those institutions represent also two of the most important regions of the country's higher education system (DGES, 2010).

The survey was administered as a paper version among master's students enrolled in seven different master's degrees, in the classroom and in the first accounting course in the master's programme (Table 1). These first accounting courses were 30 hour-long and on financial accounting. Except for the Master of Finance and the Master of Monetary, Banking and Financial Economics, the accounting courses had similar learning outcomes and were mandatory.

Like the Geiger and Ogilby (2000) study, the survey was applied at the beginning and ending of the first accounting course, which was in October 2009 and February of 2010, except for the Master of Finance and the Master of Monetary, Banking and Financial Economics which were applied in February and April of 2010. The purpose was to understand whether perceptions at the beginning have changed over the semester as it was reported in the accounting education literature, namely in Geiger and Ogilby (2000) paper.

TABLE 1: MASTER'S PROGRAMMES UNDER STUDY

\begin{tabular}{|c|c|c|}
\hline Master's Degree & Description of the master's & Institution \\
\hline $\begin{array}{l}\text { Corporate Management } \\
\text { (CORMAN) }\end{array}$ & $\begin{array}{l}\text { - One course in accounting } \\
\text { - Mandatory }\end{array}$ & \multirow{4}{*}{ University } \\
\hline Accounting (ACOUNT) & $\begin{array}{l}\text { - Several courses in accounting } \\
\text { - Mandatory }\end{array}$ & \\
\hline Finance (FINAN) & $\begin{array}{l}\text { - One course in accounting } \\
\text { - Optional }\end{array}$ & \\
\hline $\begin{array}{l}\text { Monetary, Banking and Financial } \\
\text { Economics (EMBF) }\end{array}$ & $\begin{array}{l}\text { - One course in accounting } \\
\text { - Optional }\end{array}$ & \\
\hline $\begin{array}{l}\text { Corporate Accounting and } \\
\text { Taxation (ACOTAX) }\end{array}$ & $\begin{array}{l}\text { - Several courses in accounting } \\
\text { - Mandatory }\end{array}$ & \multirow{3}{*}{ Polytechnic } \\
\hline Corporate Auditing (AUDIT) & $\begin{array}{l}\text { - One course in accounting } \\
\text { - Mandatory }\end{array}$ & \\
\hline $\begin{array}{l}\text { Management Control } \\
\text { (MANCON) }\end{array}$ & $\begin{array}{l}\text { - One course in accounting } \\
\text { - Mandatory }\end{array}$ & \\
\hline
\end{tabular}

\subsection{QUeSTIONNAIRE StRUCTURE}

Salant and Dillman's (1994) methodological approach to survey design was followed. The questionnaire was structured in two parts. In the first part, the respondent was characterised by age, gender, work experience, undergraduate degree (and its institution) and advanced graduation (and its institution). The second part was designed according to Geiger and Ogilby's (2000) paper. As these authors, the questionnaire presented ten statements regarding students' perceptions. Students were asked to indicate their level of agreement with those statements on a five-point Likert scale ranging from strongly agree ("5") to strongly disagree ("1"). The statements were 
translated from Geiger and Ogilby's (2000) paper. We used the guidelines of Chávez and Canino (2005), and followed mainly a committee approach (Marin and Marin, 1991) to translate these ten statements to Portuguese (the authors and an independent translator). We believe this translation process avoided the ambiguity problems associated with the instrument translation (Arquero and McLain, 2010), since the original instrument had no complex terminology. Table 2 presents those statements.

\section{TAble 2: Perceptions on ACCOUNting Course at the beginNing Of the Semester}

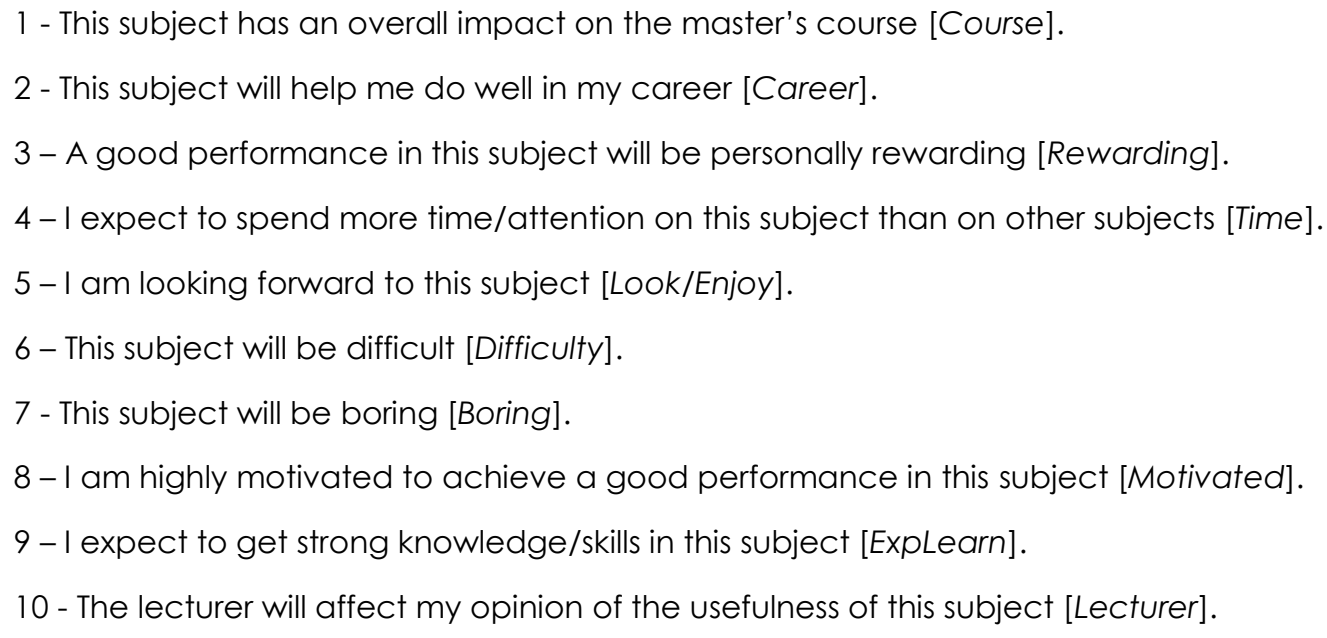

Source: These statements are based on Geiger and Ogilby (2000) study

Finally, students were questioned about their expectation regarding the final grade of the accounting course.

It is important to mention that, in Table 2, statements were designed to assess the perception prevailing between the master's students when the accounting subject was at the beginning. The students' answers enable us to understand their expectations regarding accounting.

At the end of the accounting course, the same questionnaire was conducted although changing the time verb of the statements in part two (Table 3). Just like before, students were questioned about their grade expectation and the final grade achieved in the accounting course.

In order to ensure the use of a balanced sample, cautious was taken to control the identification of the respondents at the beginning and ending of the questionnaire administration. Therefore, the matching was controlled by inserting a question (yes or no) in the questionnaire about students' participation in the study at the beginning of the accounting course and by students' identification.

Both versions of the questionnaire were pilot tested among academic staff prior to administration. 
TAble 3: Perceptions on ACCOUNting Course at the end Of the Semester

\begin{tabular}{|l|}
\multicolumn{1}{|c|}{ At the end of the semester } \\
\hline 1- This subject was very important to perform other subjects in my master's programme \\
[Course]. \\
2. This subject helped me to develop my career [Career]. \\
3- A good performance in this subject was personally gratifying [Rewarding]. \\
4- I spent more time on this subject than others [Time]. \\
5- I enjoyed this subject [Look/Enjoy]. \\
6- This subject was hard to perform [Difficulty]. \\
7- This subject was boring [Boring]. \\
8- I was always motivated to achieve a good score in this course [Motivated]. \\
9- My range of knowledge increased a lot with this subject [ExpLearn]. \\
10- The lecturer was determinant for me to be aware of the utility of the course [Lecturer]. \\
\hline
\end{tabular}

\subsection{RESPONSE RATE}

The study was applied to a total population of 200 master's students in both institutions. All students attending the lecture on the day the questionnaire was administered were invited to participate in the study. The first questionnaire obtained 162 responses $181 \%$ response rate) and the second questionnaire obtained 150 responses (75\% response rate) across all master's degrees. However, to achieve the purposes of this study, a balanced sample was used.

This meant to consider only 97 responses as valid (48.5\% response rate) because some students did not anwer to the question introduced for the matching of respondents (see Table 4) and/or it was not possible to identify the student.

Analysing the participation by institution, Polytechnic had a total of forty-five responses (47.9\% response rate) and University had fifty-two responses (49.1\% response rate), when considering the balanced sample. The sampling procedure and questionnaire response rate suggest adequate representation of the underlying population.

Thus, these samples are representative of the master's programmes available in both institutions, where the accounting course is taught as part of the master degree. Also, the sample equally represents both Portuguese higher education systems.

Finally, the authors consider that non-response bias was unlikely to be a problem of the study. The results are presented in the next section. 
TABLE 4: NUMBER OF RESPONSES AND RESPONSE RATE

\begin{tabular}{|c|c|c|c|}
\hline \multirow[b]{2}{*}{ Master's degree } & \multirow{2}{*}{$\begin{array}{l}\text { Number } \\
\text { students } \\
\text { enrolled }\end{array}$} & \multicolumn{2}{|c|}{ survey } \\
\hline & & Number & Rate \% \\
\hline ACOTAX/Polytechnic & 43 & 26 & 60.5 \\
\hline MANCON/Polytechnic & 18 & 10 & 55.6 \\
\hline AUDIT/Polytechnic & 33 & 9 & 27.3 \\
\hline Polytechnic & 94 & 45 & 47.8 \\
\hline ACOUNT/University & 40 & 14 & 35.0 \\
\hline CORMAN/University & 40 & 24 & 60.0 \\
\hline EMBF/University & 14 & 8 & 57.1 \\
\hline FINAN/University & 12 & 6 & 50.0 \\
\hline University & 106 & 52 & 49.1 \\
\hline Total & 200 & 97 & 48.5 \\
\hline
\end{tabular}

\section{RESULTS AND DISCUSSION}

The study used the one-way analysis of variance (ANOVA) and t-student test to assess the relations identified in the research framework (see Figure 3). Its aim is to understand the perception towards accounting at two different moments of time.

\subsection{Students' Characteristics}

Table 5 presents the master students' characteristics at the beginning of the accounting course. There are no international students in the sample because it is not usual to have international students enrolled at the master's degree level in the accounting subjects. The majority of the master students of our balanced sample (42\%) hold an undergraduate degree in Economics or Management field, 38\% in Accounting, Auditing or Taxation field and $20 \%$ in other fields (e.g., engineering).

As can be noticed, students from Polytechnic are older than students from University. However, the former do not possess a substantially higher level of work experience than the latter. This situation may be explained in several ways. One possible explanation is that they are older when they enter the Higher Education System, and therefore they start working later after finishing the undergraduate degree. Another possible explanation is that they spent more time finishing their undergraduate degree. Finally, it could be due to the institution where they obtained their previous degree. 
TAble 5: MAster student Characteristics (At the beginNing Of the ACCOUNTING COURSE)

\begin{tabular}{|l|c|c|c|c|c|c|c|c|c|c|}
\hline \multirow{2}{*}{$N$} & \multicolumn{4}{|c|}{ Age (years) } & \multicolumn{2}{c|}{ Gender } & \multicolumn{3}{c|}{ Working experience* (years) } \\
\cline { 2 - 11 } & Mean & $\begin{array}{c}\text { Std. } \\
\text { deviation }\end{array}$ & Min. & Max. & Female & Male & Mean & $\begin{array}{c}\text { Std. } \\
\text { deviation }\end{array}$ & Min. & Max. \\
\hline $\begin{array}{l}\text { Polytechnic } \\
\text { (n=45) }\end{array}$ & 31.76 & 8.28 & 22 & 50 & $40 \%$ & $60 \%$ & 3.91 & 4.30 & 0 & 15 \\
\hline $\begin{array}{l}\text { University } \\
\text { (n=52) }\end{array}$ & 27.52 & 7.61 & 21 & 46 & $61.5 \%$ & $38.5 \%$ & 3.17 & 4.55 & 0 & 16 \\
\hline Total & 29.48 & 8.17 & 21 & 50 & $51.5 \%$ & $48.5 \%$ & 3.52 & 4.43 & 0 & 16 \\
\hline
\end{tabular}

*after getting the undergraduate degree

Most of the Polytechnic master's students (86.7\%) got their undergraduate degree in the polytechnic system. In Portugal, the polytechnic system is known for its flexibility, namely in allowing full time worker-students to manage their professional and student life by establishing a suitable schedule for them'. However, this does not mean they can manage it successfully. Besides, University applicants have higher average grades upon entry to the Higher Education than the Polytechnic applicants ${ }^{2}$. This situation contributes for students spending more time finishing their undergraduate degree. Nevertheless, this study did not collect data to confirm these possible explanations, although research carried out recently in four Portuguese higher education institutions' MSc. revealed that there is still a large amount of diversity among institutions relatively to the average time spells required to complete identical degrees (Lopes and Fernandes, 2010. p. 3).

As for advanced graduation, only few students (twelve) invested in post-graduate training, mainly in the management field (mostly in finance), followed by accounting, taxation and auditing fields before coming to the master degree.

Finally, in what concerns their expectations regarding their grades. At the beginning of the accounting course, $92.8 \%$ of the students answered that the expected final grade was on average 13.6 (standard deviation of 4.2), in a grade scale from 0 to 20, with 10 being the minimum grade to accomplish the degree successfully. By the end of the accounting course, $88.7 \%$ of the students would expect to achieve, on average, a grade of 12.4 (standard deviation 4.9) but only eighty-seven students answered about his/her final grade (on average, 11.7 with standard deviation 5.7).

These results are explained by the continuous process of assessment faced by students (an output of the Bologna Process), which can turn them less motivated to study accounting.

\footnotetext{
1 The guidelines to access the Portuguese Public Higher Education elaborated by the Ministry of Science, Technology and Higher Education (available at http://www.dges.mctes.pt/DGES/en) provide information that sustain that polytechnic institutions frequently offer degrees in an afterwork schedule in opposition to universities.

2 This is true in the universe of business degrees and for 2009. Further research is needed to conclude if there is a trend or not.
} 


\subsection{STUDENTS' PERCEPTIONS ON ACCOUNTING}

In the second part of the questionnaire, students were asked about their perceptions on accounting following the study of Geiger and Ogilby (2000) (see Table 2).

As can be seen, master students find accounting not boring and useful for their career. These results are different from those presented in the literature review (eg., Baldwin and Ingram, 1991; Hardin et. al., 2000; Byrne and Willis, 2005; Malthus and Fowler, 2009). This can be explaining by different features of master students' population compared to undergraduate students' population. Table 6 presents the results.

\section{TABLE 6: StUdents' MEAN PERCEPTIONS}

\begin{tabular}{|c|c|c|c|c|}
\hline \multirow{3}{*}{$\begin{array}{l}N=97 \\
\text { Variable }\end{array}$} & \multirow{2}{*}{\multicolumn{2}{|c|}{$\begin{array}{l}\text { At the beginning of the } \\
\text { accounting course }\end{array}$}} & \multirow{2}{*}{\multicolumn{2}{|c|}{$\begin{array}{l}\text { At the ending of the } \\
\text { accounting course }\end{array}$}} \\
\hline & & & & \\
\hline & Mean & Std. Deviation & Mean & Std. Deviation \\
\hline Course & 4.15 & 0.65 & $3.93 \dagger$ & 0.82 \\
\hline Career & 4.31 & 0.62 & $3.67 \dagger †$ & 0.86 \\
\hline Rewarding & 4.28 & 0.75 & $3.88 \dagger †$ & 0.88 \\
\hline Time & 2.93 & 0.73 & 3.06 & 0.96 \\
\hline Look/Enjoy & 3.51 & 0.63 & $3.93 \dagger \dagger$ & 0.82 \\
\hline Difficulty & 3.34 & 0.64 & $3.07 \dagger$ & 0.93 \\
\hline Boring & 2.11 & 0.79 & 2.19 & 0.94 \\
\hline Motivated & 4.29 & 0.75 & $3.9+\dagger$ & 0.86 \\
\hline Explearn & 3.61 & 0.71 & $3.91 \dagger \dagger$ & 0.65 \\
\hline Lecturer & 3.53 & 1.01 & $3.90 \dagger$ & 0.77 \\
\hline
\end{tabular}

† Significantly different than the beginning of semester responses based on within persons t-test at $p<0.05$

†† Significantly different than the beginning of semester responses based on within persons t-test at $p<0.01$

As can be seen, master students find accounting not boring and useful for their career. These results are different from those presented in the literature review (eg., Baldwin and Ingram, 1991; Hardin et al., 2000; Byrne and Willis, 2005; Malthus and Fowler, 2009). This can be explained by different features of master students population compared to undergraduate students population.

However, and in general, the results show that students' perceptions have evolved in a negative way and this is consistent with previous literature (e.g. Geiger and Ogilby, 2000; Marriott and Marriott, 2003). At the beginning, students have higher expectations that decrease over the semester. This result was expected, since at the beginning they were very motivated to study accounting and perceived it as important for their career development and it was rewarding. But, by the end of the semester, those expectations were not matched, namely due to the demanding/continuing students work- 
assignments during the semester. The Bologna Process has changed the Portuguese Higher Education System but also implied a redevelopment of curricula that made learning more student-centered and focused on the development of competences (Cardoso et al., 2008). Before Bologna, the learning-teaching model was teachercentered and focused on knowledge transmission, where final exams were the most common instruments for evaluating students.

When the analysis goes deeper, the results show that students' perceptions are positive, although the item Time [l expect to spend more time/attention on this subject than with other subjects] is perceived as not very important. This situation can be explained by the students' work experience or student's previous knowledge on what accounting is. Thus, the accounting course in the master's degree may not be their first contact with accounting and therefore it could be perceived at first stage as not time consuming in studying it. However, we did not collect information on student's previous knowledge on accounting. Therefore, we could not test this argument but it is something that future research must consider when studying accounting perceptions at advanced degree.

It is interesting to note that, by the end of the semester, the students' motivation for achieving a good performance in the course decreased (as their expectation and their final grade revealed). At same time they recognise the importance of studying accounting, as they state their knowledge increased considerably with the accounting subject [ExpLearn] and they enjoyed studying it [Look/Enjoy]. This may be a consequence of the Bologna Process, since students did not find it harder [Difficulty]. As it has been already said, with the Bologna Process, the assessment process is in continuum with students being assessed at several moments of time.

Furthermore, this study provides empirical evidence on the importance of the lecturer (teacher) in influencing students' perceptions on accounting. This role is in general statistically significant $(p<0.01)$ and it is positive correlated with the perceptions Course, Rewarding, Motivate, Look/Enjoy and the expectation of learning [ExpLearn] (see Table 7). These results differ from those obtained by Geiger and Ogilby (2000), in which students' perceptions about the lecturer decreased over the semester. These results suggest that the students' perceptions about accounting are influenced by the role played by the lecturer, which is consistent with Hardin et al. (2000), in this case, negatively, and Whitworth et al. (2002). These findings emphasise the need to choose the best lecturers to teach the accounting subjects in order to achieve a better student perception on accounting.

Our findings do not support the argument that University and Polytechnic systems are significantly different as far as student performance ("final grade") is concerned, even though the perception on the Lecturer is positively associated with the University system $(p<0.01)$. Gender seems to significantly influence the level of Enjoy, Rewarding perceptions experienced by the students as well the influence of the lecturer on their perception on accounting. Gender is also associated with student performance, in which male students achieve higher grades. In sum, this study does not support the argument that positive perceptions are associated with student performance as found by Ferreira and Santoso (2008).

This is an exploratory study since not all the variables of this study were considered in the accounting education literature. We have considered empirically other variables for studying students' perceptions. However, variables such as the undergraduate degree field and institution or the master degree itself, and the optional/mandatory feature of the first accounting course were found statistical not significant to answer our research questions (maybe due to few number of observations). Therefore, those results are not presented here. 
Cristina Góis, Filomena Antunes

In the aftermath of Bologna process

\section{TABLE 7: MATRIX OF CORRELATIONS}

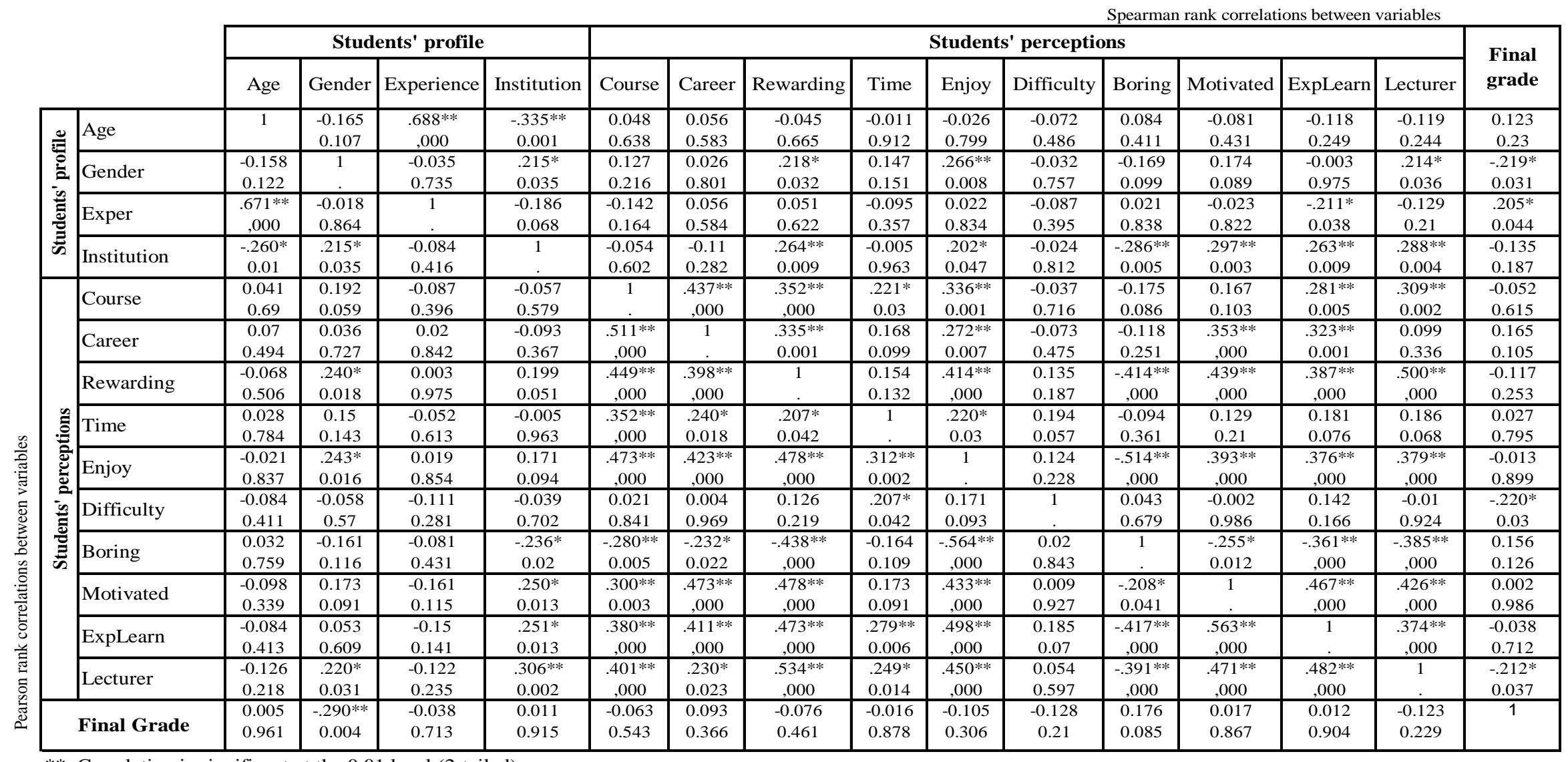

**. Correlation is significant at the 0.01 level (2-tailed)

*. Correlation is significant at the 0.05 level (2-tailed).

Variables definition: Age - years old of the master student (see table 5); Gender =1 if master student is female, 0 otherwise (male); Experience - master student's years of work experience after the undergraduate degree (see table 5); Institution = 1 if University, 0 otherwise (Polytechnic).

Course, Career, Rewarding, Time, Enjoy, Difficulty, Boring, Motivated, ExpLearn, Lecturer are caracteristics of students perceptions as defined in table 2 .

Final grade - grade achieved by the master student (in a 0-20 scale). 


\section{SUMMARY AND CONCLUSIONS}

This study aimed to explore how accounting is perceived by master students and which factors may influence these perceptions. The results show that perceptions changed over the semester, and master students do not find accounting as boring and useless as some literature pointed (e.g., Malthus and Fowler, 2009). At first, accounting course was perceived as very important in the master programme, as helping the professional career and rewarding, and therefore students were very motivated. At the end, all the perceptions values decreased in general. While this overall negative evolution is consistent with literature review (e.g. Marriott and Marriott, 2003), it is important to notice the increase of student's perception on lecturer's role in making them understand the subject and its utility, as well they enjoyed learning accounting. Besides, accounting course turns to be less difficult as previously perceived but somewhat more time consuming, though it is not statistically significant.

The research framework (Figure 3) was defined to explore the relationship between variables associated with students' characteristics (age, gender, work experience, institution) and their perceptions on accounting. In general, the study did not find any statistically significant relationship between those variables, although it found that there was a positive relationship between age and institution (older students choose to study in the polytechnic system, due to its work conditions, allowing students to balance their professional life with academic requirements) and, as expected, age and work experience. As for Gender, the study finds two statistically significant associations: one related with institutions, where female students' participation is higher in the university system than in the polytechnic system.

This supports previous empirical studies that showed that female students have been taking position in the Portuguese Higher Education (MSTHE, 2006; Lopes and Fernandes, 2010). The second association is related to student performance. It seems that male and female students perform differently, with male students performing better than female students as in Doran et al. (1991).

In general, the results did not support an association between students' perceptions on accounting and their performance (grade) on the accounting course. However, this study has some practical implications. For higher education institutions, it is important to designate lecturers that can, indeed, motivate students to learn and enjoy accounting. In addition, attention can be drawn in relation to curricular contents. In fact, Career's perception decreases significantly over the semester, which may be hiding the need to adapt curricular contents to help master students to develop their careers.

Finally, this study provides evidence suggesting that there might be differences between undergraduate students' perceptions (as reported in literature review) and graduate students (one contribution of this study). Hence, this conclusion gives support to Albrecht and Sack (2000)'s argument for structuring accounting programs differently.

Although the literature provides empirical evidence that the students' age, gender and background influence the way students perceive the accounting course and accounting competences, our study provides controversial evidence. Nevertheless, this research is important in the Portuguese framework as it provides a first answer to the question asked by Lopes and Fernandes (2010. p. 5) when they stated that "we don't know how those heterogeneous features' influence arise in Portuguese higher education neither do we know the strength of that influence along each individual trajectory". 


\section{LIMITATIONS AND FUTURE RESEARCH}

This study aimed to explore how graduate students perceive accounting and whether there is a relation with students' characteristics and performance. However, it faced several limitations.

One limitation was the sample size and that it does not represent all master's students with an accounting course in Portugal. Nevertheless, it was representative of the institutional environment studied. Thus, one tip for future research would be to gather data from other institutions to make it as representative as possible.

Another limitation was the use of grades to measure the students' performance. The authors assumed that the students' final grades were an adequate measure for student performance because in the Bologna context grade represents the sum of several moments and instruments of student assessment. Therefore, the student's grade was considered a reliable measure for student performance. Furthermore, Booth et al. (1999) found that their results were not sensitive to the use of different types of student results. Hence, despite its shortcomings, the performance variable used in this study was arguably a reasonably objective representation of the students' performance.

The survey instrument used was also a limitation. It was mainly based on the work of Geiger and Ogilby (2000). However, the aims were more focussed on studying the Portuguese students' perceptions on accounting than to prove any specific relationship, although the literature was the source for searching those relationships.

This study provided no evidence that perceptions were related with performance. Therefore, in the aftermath of the Bologna Process, it seems to be more important to know whether students are acquiring the necessary skills/competences on accounting than analysing the students' perceptions on accounting.

Finally, our study did not consider all variables that could potentially have an influence on perception and performance and, therefore, it was partially underspecified. Notwithstanding the above limitations, this study is a first insight into accounting students' perceptions and whether these perceptions affected the students' performance. Besides, this is the first study on accounting perceptions by the Portuguese students.

The results show that further research exploring the Polytechnic and University system is needed to help regulators in setting educational policies. Research on student performance, on grades and time to conclude the degree is also a future aim.

The last limitation refers to the instrument's translation process. As far as we know, few (if any) guidelines or standards have been established in accounting education literature for the translation and cultural adaptation of instruments. Therefore, little is reported in research publications about the translation process of instruments. In this study, it was followed the committee translation process. However, this approach has also its limitations. The shortcoming of this method is that committee members can have the same world view or have similar backgrounds which lead them to produce the translated instrument skewed one way (Marin and Marin, 1991). Yet, as Portuguese students are strongly adverse to literature written in English, it would be inappropriate to use an English questionnaire because of the response rate.

\section{REFERENCES}

Accounting Education Change COMmISSION, AECC [1992]: The first course in accounting: position statement, Issues in Accounting Education, vol.7, núm.2: 249-251. 
ALBRECHT, W.S. Y SACK, R. [2000]: Accounting education: charting the course through a perilous future, Accounting Education Series, 16, Sarasota, FL, American Accounting Association.

AMEEN, E.C., GufFEY, D.M. y MCMILLAN, J.J. [2004]: Gender differences in determining the ethical sensitivity of future accounting professionals, Journal of Business Ethics, vol. 15, núm. 5: 591-597.

ARENDALE, D. [1994]: Understanding the supplemental instruction model, in: DC Martin and D Arendale (Eds.) Supplemental Instruction: Increasing Achievement and Retention, San Francisco, CA, Jossey-Bass, Inc..

ARQUERO, J.L. y MCLAIN, D.L. [2010]: Preliminary Validation of the Spanish Version of the Multiple Stimulus Types Ambiguity Tolerance Scale (MSTAT-II), The Spanish Journal of Psychology, vol. 13, núm. 1: 476-484.

BALDWIN, B.A. Y INGRAM, R.W. [1991]: Rethinking the objectives and contentment of elementary accounting, Journal of Accounting Education, vol. 9, num. 1:1-14.

Barañano, A. M. [2004]. Métodos e Técnicas de Investigação em Gestão, Lisboa: Edições Sílabo.

Bergan, S. y RAUHVARgers, A. [2006]: Recognition in the Bologna Process: policy development and the road to good practice, Council of Europe higher education series No.4.

BERRY, K. T., O'BRYAN, D. Y SWANSON, P.K. [2004]: High school business educators' perceptions of the knowledge, skills, and abilities needed by accounting majors relative to other business majors. Accounting Instructors' Report, Spring, 2004. Retrieved on November 6, 2010 from http://college.hmco.com/accounting/resources/instructors/air/index.html

BOOTH, P., LUCKETT, P. Y MLAVEDONIC, R. [1999]: The quality of learning in accounting education: the impact of approaches to learning on academic performance, Accounting Education, vol. 8, num. 4: 277-300.

BOUILLON, M. L. y DORAN, B. M. [1992]: The relative performance of female and male students in accounting principles classes, Journal of Education for Business, vol. 67, núm. 4: 224-228.

BUCKLESS, F. A., LIPE, M. G. y RAVENSCROFt, S. P. [1991]: Do gender effects on accounting course performance persist after controlling for general academic aptitude?, Issues in Accounting Education, vol. 6:13-23.

BYRNE, M. Y WILLIS, P. [2005]: Irish secondary student's perception of the work of an accountant and the accounting profession, Accounting Education, vol. 14, num. 4:367-381.

BYRNE, M., FLOOD, B. y WILLIS, P. [2002]: The relationship between learning approaches and learning outcomes: a study of Irish accounting students, Accounting Education: an International Journal, vol. 11, núm. 1: 27 - 42.

Cardoso, A.R., Portela, M., SÁ, C. y Alexandre, F. [2008]: Demand for Higher Education Programs: The Impact of the Bologna Process, CESifo Economic Studies, vol. 54, num. 2: 229-247.

CHÁVEZ, L. M Y CANINO, G. [2005]: [http://www.hsri.org/files/uploads/publications/ PN54_Translating_and_Adapting.pdf]

COHEN, J. Y HANNO, D. M. [1993]: An analysis of underlying constructs affecting the choice of accounting as a major. Issues in Accounting Education (Vol. 8, No. 2) 219-238.

COOPER, D. R. y SCHINDLER, P.S. [1998]: Business Research Methods, McGraw-Hill International Editions, $6^{\text {th }}$ Edition.

DIRECÇÃO GERAL DO ENSINO SUPERIOR, DGES [2009]: Rede do Ensino Superior, Lisboa.

DIRECÇÃO GERAL DO ENSINO SUPERIOR, DGES [2010]: Bolonha: Grandes números - Estudo 2 Distribuição por áreas científicas e distritos, Retrieved on June 21, from http://www.dges.mctes.pt/NR/rdonlyres/99CEE606-990E-4CB4-A8AC-

FAF7AAD58B/4167/ BolonhaGN Estudo2Areas.pdf 
DONELAN, J.G y REED, R.O. [1992]: Characteristics of accounting programs: A survey of students' perceptions. Journal of Accounting Education, vol. 10, num. 1:191209.

DORAN, B., BOUILLON, M.L. y SMITH, C.G. [1991]: Determinants of student performance in accounting principles I and II", Issues in Accounting Education, vol. 6: 74-84.

EUROPEAN UNIVERSITY ASSOCIATION, EUA [2012]: What is Bologna Process?, Retrieved on July 20, from http://www.eua.be/eua-work-and-policy-area/building-theeuropean-higher-education-area/bologna-basics.aspx

FERNANDES, D. [2009]: Characteristics of Educational Assessment Systems Worldwide Educational Assessment in Portugal, Assessment in Education: principles, Policy and Practice, vol. 16, núm. 2: 227-247.

FERreira, A. y SANTOSO, A. [2008]: Do students' perceptions matter? A study of the effect of students' perceptions on academic performance, Accounting and Finance, vol. 48:209-231.

GeIGER, M.A. y OGILBY, S.M. [2000]: The first course in accounting: students' perceptions and their effect on the decision to major in accounting, Journal of Accounting Education, vol.18:63-78.

HARDIN, R., D. O'BRYAN, y QUIRIN, J. [2000]: Accounting versus engineering, law, and medicine: perceptions of influential high school teachers, Advances in Accounting, vol. 17: 205-220.

HARRISON, S. [1998]: Are accountants obsolete? Charter, vol. 69, num. 9: 6.

INMAN, B. C., WENZLER, A. Y WICKERT, P.D. [1989]: Square pegs in round holes: Are accounting students well-suited to today's accounting profession? Issues in Accounting Education, vol. 4, núm.1:29-47.

KeELING, R. [2006]: The Bologna Process and the Lisbon Research Agenda: The European Commission's expanding role in higher education discourse European Journal of Education, vol. 41, num. 2: 203-223.

LIPE, M. G. [1989]: Further evidence on the performance of female versus male accounting students, Issues in Accounting Education, vol. 1:144-152.

LOPES, M. C. y FeRnANDES, G. L. [2010]: Success/Failure in HE: how long does it take to complete some core 1st year disciplines?, MPRA Paper No 21953, University Library of Munich, Germany.

MAKSY, M. M. Y ZHENG, L. [2008]: Factors associated with student performance in advanced accounting and auditing: and empirical study in a public university, Accounting Research Journal, vol. 21, num. 1:16-32.

MALGWI, C. A. [2006]: Discerning Accounting And Non-Accounting Students' Perceptions In The First Course In Accounting As A Proxy For Separate Course Delivery, Global Perspectives on Accounting Education, vol. 3: 67-91.

Malthus, S. y Fowler, C. (2009): Perceptions of accounting: a qualitative New Zealand study. Pacific Accounting Review, vol. 21, num. 1:26-47.

MARIN, G. L. Y MARIN, B. A. V. [1991]: Research with Hispanic Populations. Applied Social Research Methods Series, vol. 23, Newbury Park, CA: Sage Publications.

MARRIOTT, P. Y Marriot, N. [2003]: Are we turning them on? A longitudinal study of undergraduate accounting students' attitudes toward accounting as a profession, Accounting Education: an international journal, vol.12, num. 2:113133.

MARTINS, S. C., MAURITTI, R. y COSTA, A.F. [2005]: Condições Socioeconómicas dos Estudantes do Ensino Superior em Portugal, DGES, Portuguese Ministry of Science, Technology and Higher Education.

MUTCHLER, J. E., TURNER, T. H. y WILLIAMS, D.D. [1987]: The performance of female versus male accounting students, Issues in Accounting Education, vol. 1:103-111.

Nelson, I. T., VeNDRZYK, V. P., QUIRIN, J. J. y AlLEN, R. D. [2002]: No, the sky is not falling: evidence of accounting student characteristics at FSA schools, 1995-2000, Issues in Accounting Education, vol.17, num. 3:269-287. 
PAOLILLO, J. G. y ESTES, G. W. [1982]: An empirical analysis of career choice factors among accountants, attorneys, engineers, and physicians. The Accounting Review, vol. 4: 785-793.

Portuguese Ministry OF SCIENCE, TeChnology and Higher EduCAtion, MSTHE [2006]: Country Background Report: Portugal, in OECD Thematic Review of Tertiary Education, 1-99.

RAO, A., y HIGGINS, L. [1999]: First course in accounting from the user's perspective: a case study of the use of a financial statement analysis project utilizing internet research, Journal of Accounting and Financial Research, vol. 17, num. 2:29-50.

SAEMANN, G. P. y CROOKER, K. J. [1999]: Student perceptions of the profession and its effect on decisions to major in accounting. Journal of Accounting Education, vol. 17, num. 1: 1-22.

Salant, P. y Dillman's, D.A. [1994]: How to conduct Your Own Survey, New York: John Wiles and Sons.

Sugahara, S., KURIHARA, O. y Boland, G. [2006]: Japanese Secondary School Teachers' Perceptions of the Accounting Profession, Accounting Education: an International Journal, vol. 15, num. 4: 405-418.

WeLLS, P. K. [2009]: Perceptions of accounting and accountants: an investigation into how and why these perceptions were formed. PhD Thesis, Auckland University of Technology.

WeLLS, P. K. y FIEGER, P. [2006]: High school teachers' perceptions of accounting: An international study. Australian Journal of Accounting Education, vol. 12, nun. 1: 29-51.

WHITWORTH, J. E., PRICE, B. A. Y RANDALL, C. H. [2002]: Factors that affect college of business student opinion of teaching and learning, Journal of Education for Business, vol. 77, num. 5: 282-289.

WILLIAMS, D. Z. [1991]: The accounting education change commission and curriculum development, in: G. L. Sundem and C.T. Norgaard (Eds.), Models of Accounting Education, Torrance, CA, Accounting Education Change Commission, 33-37. 